\title{
Predicting professional school performance with a unique lens: are there other cognitive predictors?
}

\author{
Theresa A. Davies ${ }^{1,2^{*}}$ (D), Madeline B. Miller ${ }^{2}$, Vincent A. Moore ${ }^{1}$ and Elizabeth A. Kaye ${ }^{3}$
}

\begin{abstract}
Background: We investigated the associations between admissions criteria and performance in four cohorts of predental MS in Oral Health Sciences (OHS) program at Boston University Schools of Medicine and Dental Medicine. Previously we have reported that OHS serves as a successful pre-dental pipeline program for students from underrepresented groups.

Methods: We evaluated academic variables that further affect overall graduate GPA and grades in the first year dental school courses taken by OHS students at Boston University between 2012 and 2016 as part of the MS curriculum. Demographic data, region of residency, undergraduate grade point average, number of science and math credits, major of study, dental admissions test scores and undergraduate institution were collected. The competitiveness of the undergraduate institution was scored based on Barron's Profiles of American Colleges. OHSGPA was assessed and individual grades in two first year dental school courses taken as part of the OHS curriculum were collected. Analysis of variance, the Chi-square test and Fisher's Exact test were utilized to assess associations between academic performance parameters, successful program completion and matriculation to dental school.
\end{abstract}

Results: Results indicate that undergraduate major, age and number of science course credits taken had no impact on MS performance in the Boston University MS in Oral Health Sciences program; however, students who took an undergraduate course in Physiology performed better than those who did not $(p=0.034)$. This was not the case with courses in Cell Biology and Biochemistry. Students with DAT scores over 20 academic average $(p=0.001), 18$ total science average $(p=0.001)$ and 22 reading comprehension $(p=0.004)$ performed better in dental school courses taken in OHS.

Conclusion: We report that strong test scores, attending a mid or highly rigorous undergraduate institution and completion of an undergraduate Physiology course are positive predictors. We hope these findings will guide admission's decisions and improve recruitment to, and future success of, graduate student's pursuit of professional school. Understanding alternative predictors of success may help to reduce the intrinsic bias among applicants from underrepresented groups and continue to look beyond the DATs (or MCATs) to decrease the gap between professionals from underrepresented groups and those they serve.

Keywords: Admissions criteria, Academic performance, Underrepresented groups, Pipeline, Dental, Medical, DAT

\footnotetext{
*Correspondence: tdavies@bu.edu

'Department of Medical Sciences \& Education, Boston University School of Medicine, Boston, MA, USA

${ }^{2}$ Graduate Medical Sciences, Boston University School of Medicine, 72 East

Concord Street, L317, Boston, MA 02118, USA

Full list of author information is available at the end of the article
}

(c) The Author(s). 2020 Open Access This article is distributed under the terms of the Creative Commons Attribution 4.0 International License (http://creativecommons.org/licenses/by/4.0/), which permits unrestricted use, distribution, and reproduction in any medium, provided you give appropriate credit to the original author(s) and the source, provide a link to the Creative Commons license, and indicate if changes were made. The Creative Commons Public Domain Dedication waiver (http://creativecommons.org/publicdomain/zero/1.0/) applies to the data made available in this article, unless otherwise stated. 


\section{Background}

Admission to medical and dental schools as well as doctoral programs in the biomedical sciences is extremely competitive. In hope of ensuring a successful candidate, professional schools have moved towards a holistic review and the use of a combination of cognitive and noncognitive attributes to assess applicants [1]. Cognitive domains encompass those that are quantitative (undergraduate GPA, standardized exams), while noncognitive domains are qualitative (interview, letters of recommendation, emotional intelligence). Unfortunately, many of these factors have been shown to have a statistically insignificant correlation with academic success and more longitudinal studies examining predictors of success after admission are needed.

Commonly, the first set of data evaluated by admissions committees are the cognitive skills. Standardized test scores such as the graduate record exam (GRE) and undergraduate GPA (UGPA) often are the determining factor for an applicant to progress within the admission system. Setting minimum criteria for admission based on test scores such as the GREs has shown modest consistency in reported studies over the past decade [2]. In dental admissions, studies have been mixed. A study from the University of Florida College of Dentistry of graduating classes from 1994 to 1999 [3] as well Harvard Dental School supported the positive correlation between the UGPA and success in dental school [4]. Similar results were reported by Lee et al. at Columbia University College of Dental Medicine [5] and Plouffe et al. at Schulich School of Medicine \& Dentistry, University of Western Ontario, Canada [6]. Plouffe states that DAT chemistry scores serve as positive predictors of successful dental school performance. Rowland \& Rieken evaluated six classes from 2007 to 2013 at Southern Illinois School of Dental Medicine and noted that while there was a strong correlation between overall UGPA and performance in dental school, they noted this only accounted for $40 \%$ of the variance in GPA among the first year of dental school. Other factors, such as science GPA and test section sub-scores, they reported, were important in assessing performance although they also noted that factors such as emotional intelligence were relevant as well [7]. They note that this correlation is not a significant determining factor because there were students that outperformed the prediction and students who significantly underperformed the projected dental school GPA based on this admission criteria [7]. This data is consistent with a study done at University of California, Davis School of Medicine that showed students who were admitted with a Medical College Admissions Test (MCAT) score and UGPA below the minimum requirement outperformed many of the individuals who were admitted who met the standard minimum requirements [8]. Park et al. evaluated performance in doctoral students in the biomedical sciences at Boston University and demonstrated a significant positive correlation between academic performance in year 1 of doctoral graduate study and undergraduate GPA and GRE scores [9]. They also used undergraduate institution rigor to normalize UGPA, a factor that is often not included when discussing UGPA.

Noncognitive abilities have been evaluated in a doctoral program at University of Ottawa Medical School however a clear correlation among these abilities and academic success were inconclusive [10]. These results are similar to those found by Plouffe et al. evaluating interview scores to assess communication, interpersonal skills, resiliency, and integrity [6]. They found there was no positive correlation between interview score and any other preadmission variable or dental school grades. On the contrary, emotional intelligence has been reported to positively correlate with clinical performance among students who communicate effectively and show interpersonal sensitivity in their interactions with patients [11]. Further, studies evaluating DAT test sub-scores with clinical performance have been less successful [8] .

While cognitive and noncognitive abilities are used as predictors for performance in most doctoral professional programs who strive for holistic review, there continues to be a need for further longitudinal studies on the contribution of both cognitive and noncognitive attributes in admissions selections. In the changing and evermore competitive academic environment, applicants have sought out academic enrichment master's programs as a means to enhance their credentials for medical and dental school admission as well as enhance their professional development. The MS in Oral Health Sciences (OHS) program is one such program geared to strengthen an applicant's credentials for dental school admission. The OHS program was developed in 2005 by Boston University Henry M. Goldman School of Dental Medicine in collaboration with Graduate Medical Sciences at Boston University School of Medicine. The 32-credit program over its first 10 years has graduated more than 200 students with more than $90 \%$ of its graduates matriculating to (enrolling in) dental school [12]. Additionally, more than $25 \%$ of OHS graduates have come from groups under-represented in the field of dentistry thus serving as a pipeline program [12]. Previous work demonstrated that a strong performance in the OHS master's program $(p<$ 0.001 ) is predictive of future dental school success as measured by matriculation to (or enrollment in) dental school and success in the first two years of didactics. These results are strong; however, we are still working to improve our admissions criteria in order to better predict student success both in OHS as well as subsequently in dental school. Here we continue this work by evaluating academic variables from both their undergraduate and graduate years that may serve as additional positive predictors 
for future dental school success including undergraduate school rigor and specific coursework.

\section{Methods}

\section{Ethics}

The study was an analysis of de-identified data. This study was determined to be EXEMPT by the Institutional Review Board of Boston University Medical Campus, Protocol \# H-33295.

\section{Data collection}

Data for students enrolled in the OHS program at Boston University between 2012 and 2016 were utilized. Data on their gender, age, region of residency, undergraduate grade point average (GPA), number of science (Biology, Chemistry, Physics (BCP)) and math credits (BCPM), major of study, dental admissions test (DAT) scores and undergraduate institution attended were collected from admissions records to the master's program. The competitiveness of the undergraduate institution was scored based on Barron's Profiles of American Colleges on a scale of one to three, with one representing the most competitive institution [13].

Academic performance in the OHS graduate program was collected from the Graduate Medical Sciences Registrar. Overall OHS-GPA was assessed as well as individual grades in two first year dental school courses $(\mathrm{OH}$ 730 Physiology, OH 751 Biochemistry) taken as part of the OHS curriculum. These two courses are BU School of Dental Medicine year one courses and OHS students, as part of their graduate curriculum, enroll in these courses to demonstrate academic readiness for the rigors of dental school. OHS student sit side-by-side first year BU sdental students. If the OHS students took the DAT more than once, the best score was used in the analysis.

\section{Data analysis}

Analysis of variance, the Chi-square test and Fisher's Exact test were utilized to assess associations between academic performance parameters, successful program completion and enrollment in dental school.

Multivariable linear and logistic regression models were constructed to identify the most important independent predictors of OHS-GPA and performance in first year dental school courses, respectively. The models initially included variables that were significantly associated with those outcomes in bivariate analyses. These variables were age, gender, undergraduate school rigor, undergraduate school region, undergraduate physiology course, DAT total science score, and DAT reading comprehension score. Selection of the final models was performed in a stepwise manner and variables were allowed to stay in the model if their $P$ value was $<0.05$.

\section{Results}

Demographics and undergraduate credentials

Pre-admissions data was collected for 129 enrolled OHS master's students (Table 1); gender breakdown was slightly more female, most enrollees had attended an undergraduate institution grouped in the mid or highly rigorous category and the majority chose to major in a science. Approximately $50 \%$ of enrollees to the OHS program had previously applied to dental school and were unsuccessful in gaining admission. The cohort was $8 \%$ African American, 27\% Asian, 20\% Latino/Hispanic, 1\% Native American and 44\% White. Average undergraduate GPA was $3.10 \pm 0.26$ while DAT scores were competitive ranging from 18.8 to 21 for academic average, reading comprehension and total science sub scores.

\section{OHS student performance in dental classes by undergraduate predictors}

The majority of students (58\%) students earned a $\mathrm{B}+$ or better in dental school Physiology with 7\% failing while more than $65 \%$ performed better in dental school Biochemistry with comparable non-passing grades (6\%) (Table 2).

Students from the mid-West compared to those from Massachusetts $(p=0.036)$ and younger students $(<23$ year; $p=0.014$ ) performed stronger academically (Table 3 ). When performance in dental school Physiology and Biochemistry were compared, both the male gender $(p=$ $0.035)$ and students less than 23 years old $(p=0.026)$ performed significantly better than other cohorts (Table 3 ).

\section{Relationship between DAT and OHS student performance in dental classes}

Students with academic average DAT scores of 20 and above $(p<0.001)$, total science 18 and above average $(\mathrm{p}<0.001)$ and reading comprehension 22 and above $(p=0.004)$ performed better in both dental school courses and overall in the OHS master's program as measured by OHS GPA (Table 4). Conversely, undergraduate GPA was not associated with performance in OHS. Students attending a less rigorous undergraduate institution did not perform as well as students attending a higher or mid-range rigor college in both dental school courses and overall in the OHS program (Table 4).

Students who enrolled in an undergraduate Physiology course performed better in dental school courses and overall in the OHS program. This was not the case with undergraduate courses in Anatomy \& Physiology, Cell Biology or Biochemistry $(p=0.034)$ (Table 4$)$.

\section{Relationship between undergraduate and OHS student performance and matriculation to dental school}

A large number of OHS graduates matriculated to BU School of Dental Medicine (67\%) with Tufts accepting 12 , and $17 \%$ attending other schools across the country 
Table 1 Characteristics of OHS cohort upon entry into program $(N=129)$. Mean \pm SD or $\%$

\begin{tabular}{|c|c|}
\hline Age & $24 \pm 2$ \\
\hline \multicolumn{2}{|l|}{ Gender } \\
\hline Female & $72(56 \%)$ \\
\hline Male & $57(44 \%)$ \\
\hline \multicolumn{2}{|l|}{ Race / Ethnicity } \\
\hline African American & $10(8 \%)$ \\
\hline Asian & $35(27 \%)$ \\
\hline Latino/Hispanic & $26(20 \%)$ \\
\hline Native American & $1(<1 \%)$ \\
\hline White & $57(44 \%)$ \\
\hline \multicolumn{2}{|l|}{ Undergraduate School Rigor } \\
\hline Low & $23(17 \%)$ \\
\hline Mid & $51(40 \%)$ \\
\hline High & $55(43 \%)$ \\
\hline \multicolumn{2}{|l|}{ Undergraduate Major } \\
\hline Biology, Chemistry, Physiology & $92(71 \%)$ \\
\hline Health Sciences & $12(9 \%)$ \\
\hline Anthropology, Human Behavior & $6(5 \%)$ \\
\hline Engineering, Math & $3(2 \%)$ \\
\hline Business & $5(4 \%)$ \\
\hline Other & $11(9 \%)$ \\
\hline \multicolumn{2}{|l|}{ Undergraduate School Region } \\
\hline Massachusetts & $35(27 \%)$ \\
\hline Other New England & $15(12 \%)$ \\
\hline Mid-Atlantic, Maryland, Washington DC & $23(18 \%)$ \\
\hline South & $24(19 \%)$ \\
\hline Midwest & $14(11 \%)$ \\
\hline West & $17(13 \%)$ \\
\hline Outside US & $1(1 \%)$ \\
\hline Undergraduate GPA & $3.10 \pm 0.26$ \\
\hline \# Undergraduate BCP credits & $68 \pm 20$ \\
\hline \# Undergraduate BCPM credits & $80 \pm 22$ \\
\hline Took undergraduate Anatomy \& Physiology course & $57(44 \%)$ \\
\hline Took undergraduate Biochemistry course & $105(81 \%)$ \\
\hline Took undergraduate Cell Biology course & $77(60 \%)$ \\
\hline Took undergraduate Microbiology course & $71(55 \%)$ \\
\hline Took undergraduate Physiology course & $78(61 \%)$ \\
\hline Previously applied to dental school & $69(53 \%)$ \\
\hline DAT Academic Average & $19.6 \pm 2.0$ \\
\hline DAT Reading Comprehension & $21.0 \pm 2.4$ \\
\hline DAT Total Science & $18.8 \pm 1.7$ \\
\hline Previously applied to dental school & $69(54 \%)$ \\
\hline
\end{tabular}

Table 2 OHS Student performance in dental school courses taken as part of the OHS curriculum $(\mathrm{N}=129){ }^{*}$ Mean \pm SD

\begin{tabular}{ll}
\hline OHS Physiology Grade (dental school course) & \\
\hline A & $16(12 \%)$ \\
\hline A- & $15(12 \%)$ \\
B+ & $44(34 \%)$ \\
B & $22(17 \%)$ \\
B- & $25(19 \%)$ \\
C+ & $3(2 \%)$ \\
C & $3(2 \%)$ \\
C- & $1(1 \%)$ \\
B+ or higher & $75(58 \%)$ \\
OHS Biochemistry Grade (dental school course) & \\
A & $24(19 \%)$ \\
A- & $27(21 \%)$ \\
B+ & $33(26 \%)$ \\
B & $24(19 \%)$ \\
B- & $15(12 \%)$ \\
C+ & $4(3 \%)$ \\
C & $2(2 \%)$ \\
B+ or higher & $84(65 \%)$ \\
\hline &
\end{tabular}

including Meharry, New York University, University of New England, Detroit Mercy and Columbia. There were eight students or $6 \%$ who did not gain admission to any dental school. The dental school matriculation rate for the cohort was $94 \%$.

Age $(p=0.32)$ and gender $(p=0.73)$ did not correlate with admissions to dental school however fewer students matriculated to dental school from less rigorous schools $(p=0.034)$ (Table 5). There was however a correlation between students earning a $\mathrm{B}+$ or better in both dental school courses (Biochemistry $p=0.003$ and Physiology $p=0.009)$ as well as overall GPA in the OHS program $(p<0.001)$ (Table 5).

\section{Multivariable regression}

The significant independent predictors of OHS-GPA were undergraduate school rigor $(P<0.001)$, DAT total science score $(\mathrm{P}<0.001)$, and DAT reading comprehension score $(P<0.05)$. Having attended a mid-rigor school compared to a low-rigor school resulted in an average increase in OHSGPA of $0.12 \pm 0.06$ whereas attending a high rigor school increased OHS-GPA by $0.20 \pm 0.06$. Each 5 -point increment of the DAT total science score increased OHS-GPA by $0.29 \pm 0.07$ and each 5-point increment of the DAT reading comprehension score increased it by $0.12 \pm 0.05$.

Significant predictors of a $\mathrm{B}+$ or higher grade in the first year dental school physiology course also included undergraduate school rigor $(P<0.01)$, DAT total science 
Table 3 Performance in OHS by undergraduate predictors † Means with matching symbol are significantly different $(N=129)$. Mean \pm SD or $\%$

\begin{tabular}{|c|c|c|c|c|}
\hline & $\mathrm{N}$ & $\begin{array}{l}\text { Mean OHS GPA (Mean } \pm \\
\text { SD) }\end{array}$ & $\begin{array}{l}\% \text { B+ or better grade in } \mathrm{OHS} \\
\text { Physiology }\end{array}$ & $\begin{array}{l}\% \text { B+ or better grade in } \mathrm{OHS} \\
\text { Biochemistry }\end{array}$ \\
\hline \multicolumn{5}{|l|}{ Gender } \\
\hline Female & 72 & $3.49 \pm 0.27$ & 50 & 61 \\
\hline Male & 57 & $3.51 \pm 0.27$ & 68 & 70 \\
\hline$P$ value & & 0.69 & 0.035 & 0.28 \\
\hline \multicolumn{5}{|l|}{ Age } \\
\hline$<=23$ & 79 & $3.55 \pm 0.26$ & 66 & 70 \\
\hline$>23$ & 50 & $3.43 \pm 0.26$ & 46 & 58 \\
\hline$P$ value & & .014 & .026 & .18 \\
\hline \multicolumn{5}{|l|}{ Undergraduate Major } \\
\hline Biology, Chemistry, Physiology & 92 & $3.51 \pm 0.27$ & 58 & 67 \\
\hline Health Sciences & 12 & $3.49 \pm 0.26$ & 50 & 67 \\
\hline Anthropology, Human Behavior & 6 & $3.35 \pm 0.26$ & 50 & 50 \\
\hline Engineering, Math & 3 & $3.57 \pm 0.20$ & 67 & 67 \\
\hline Business & 5 & $3.42 \pm 0.18$ & 60 & 20 \\
\hline Other & 11 & $3.60 \pm 0.26$ & 73 & 73 \\
\hline$P$ value & & .53 & .91 & .35 \\
\hline \multicolumn{5}{|l|}{ Undergraduate School Region } \\
\hline Massachusetts & 35 & $3.40 \pm 0.26+$ & 46 & 63 \\
\hline Other New England & 15 & $3.49 \pm 0.25$ & 53 & 53 \\
\hline $\begin{array}{l}\text { Mid-Atlantic, Maryland, Washington } \\
\text { DC }\end{array}$ & 23 & $3.52 \pm 0.22$ & 70 & 65 \\
\hline South & 24 & $3.56 \pm 0.25$ & 54 & 63 \\
\hline Midwest & 14 & $3.65 \pm 0.28+$ & 78 & 86 \\
\hline West & 17 & $3.47 \pm 0.30$ & 59 & 65 \\
\hline Outside US & 1 & 3.88 & 100 & 100 \\
\hline$P$ value & & .036 & .33 & .65 \\
\hline \multicolumn{5}{|l|}{ \# Undergraduate BCP credits } \\
\hline$<=53$ & 26 & $3.48 \pm 0.25$ & 54 & 50 \\
\hline $54-66$ & 36 & $3.46 \pm 0.29$ & 53 & 58 \\
\hline $67-75$ & 33 & $3.52 \pm 0.25$ & 64 & 73 \\
\hline$>=76$ & 34 & $3.54 \pm 0.28$ & 62 & 77 \\
\hline$P$ value & & .64 & .75 & .11 \\
\hline \multicolumn{5}{|l|}{ \# Undergraduate BCPM credits } \\
\hline$<=66$ & 32 & $3.48 \pm 0.27$ & 56 & 50 \\
\hline $67-75$ & 26 & $3.48 \pm 0.31$ & 54 & 62 \\
\hline $76-87$ & 38 & $3.54 \pm 0.25$ & 63 & 76 \\
\hline$>=88$ & 33 & $3.49 \pm 0.25$ & 58 & 70 \\
\hline$P$ value & & .74 & .89 & .12 \\
\hline
\end{tabular}

score $(\mathrm{P}<0.01)$, and DAT reading comprehension score $(P<0.05)$. Achieving a $\mathrm{B}+$ or higher grade in the first year dental school biochemistry course was related to having taken an undergrad physiology course $(p<0.05)$ and DAT total science score $(\mathrm{P}<0.01)$.

\section{Discussion}

The OHS master's program at Boston University has previously been shown to be an excellent credential enhancing pre-dental pipeline program [12]. This study demonstrated that a strong performance in the rigorous 
Table 4 Performance in OHS by DAT, undergraduate coursework and school rigor predictors. $(\mathrm{N}=129)$. Mean \pm SD or \%. $\neq$ Significantly different from lowest quartile/group

\begin{tabular}{|c|c|c|c|c|}
\hline & $\mathrm{N}$ & Mean OHS GPA & $\%$ B+ or better grade in OHS Physiology & $\% \mathrm{~B}+$ or better grade in OHS Biochemistry \\
\hline \multicolumn{5}{|c|}{ DAT Academic Average } \\
\hline$<=18$ & 37 & $3.36 \pm 0.25$ & 30 & 46 \\
\hline 19 & 30 & $3.44 \pm 0.26$ & 43 & 57 \\
\hline $20-21$ & 44 & $3.59 \pm 0.22 \neq$ & 77 & 80 \\
\hline$>=22$ & 18 & $3.67 \pm 0.25 \neq$ & 94 & 83 \\
\hline$P$ value & & $<0.001$ & $<0.001$ & .004 \\
\hline \multicolumn{5}{|c|}{ DAT Reading Comprehension } \\
\hline$<=19$ & 33 & $3.40 \pm 0.28$ & 33 & 55 \\
\hline $20-21$ & 48 & $3.47 \pm 0.25$ & 58 & 60 \\
\hline 22 & 21 & $3.62 \pm 0.20 \neq$ & 76 & 81 \\
\hline$>=23$ & 27 & $3.60 \pm 0.28 \neq$ & 74 & 74 \\
\hline$P$ value & & .004 & .003 & .15 \\
\hline \multicolumn{5}{|c|}{ DAT Total Science } \\
\hline$<=17$ & 27 & $3.29 \pm 0.26$ & 30 & 41 \\
\hline 18 & 32 & $3.53 \pm 0.24 \neq$ & 59 & 66 \\
\hline $19-20$ & 48 & $3.53 \pm 0.23 \neq$ & 58 & 69 \\
\hline$>=21$ & 22 & $3.65 \pm 0.25 \neq$ & 91 & 86 \\
\hline$P$ value & & $<0.001$ & $<0.001$ & .008 \\
\hline \multicolumn{5}{|c|}{ Undergraduate GPA } \\
\hline$<=2.93$ & 31 & $3.43 \pm 0.23$ & 48 & 65 \\
\hline $2.94-3.10$ & 32 & $3.53 \pm 0.26$ & 63 & 69 \\
\hline $3.11-3.25$ & 33 & $3.53 \pm 0.24$ & 61 & 61 \\
\hline$>=3.26$ & 33 & $3.52 \pm 0.32$ & 61 & 67 \\
\hline$P$ value & & .35 & .65 & .91 \\
\hline \multicolumn{5}{|c|}{ Undergraduate School Rigor } \\
\hline Low & 23 & $3.33 \pm 0.29$ & 22 & 44 \\
\hline Mid & 51 & $3.49 \pm 0.23$ & 57 & 67 \\
\hline High & 55 & $3.58 \pm 0.25 \neq$ & 75 & 73 \\
\hline$P$ value & & $<0.001$ & $<0.001$ & .045 \\
\hline \multicolumn{5}{|c|}{ Took undergraduate Anatomy \& Physiology } \\
\hline Yes & 57 & $3.49 \pm 0.28$ & 63 & 68 \\
\hline No & 72 & $3.51 \pm 0.26$ & 54 & 63 \\
\hline$P$ value & & .66 & .30 & .48 \\
\hline \multicolumn{5}{|c|}{ Took undergraduate Biochemistry course } \\
\hline Yes & 105 & $3.50 \pm 0.26$ & 58 & 66 \\
\hline No & 24 & $3.50 \pm 0.30$ & 58 & 63 \\
\hline$P$ value & & .96 & .98 & .77 \\
\hline \multicolumn{5}{|c|}{ Took undergraduate Cell Biology course } \\
\hline Yes & 77 & $3.51 \pm 0.28$ & 62 & 69 \\
\hline No & 52 & $3.49 \pm 0.25$ & 52 & 60 \\
\hline$P$ value & & .64 & .24 & .28 \\
\hline
\end{tabular}


Table 4 Performance in OHS by DAT, undergraduate coursework and school rigor predictors. $(\mathrm{N}=129)$. Mean \pm SD or \%. $\neq$ Significantly different from lowest quartile/group (Continued)

\begin{tabular}{lrrrr}
\hline & $N$ & Mean OHS GPA & \% B+ or better grade in OHS Physiology & $\%$ B+ or better grade in OHS Biochemistry \\
\hline & & & Took undergraduate Physiology course & 74 \\
Yes & 78 & $3.54 \pm 0.26$ & 63 & 51 \\
No & 51 & $3.44 \pm 0.27$ & 51 & .007 \\
P value & & .034 & .18 &
\end{tabular}

OHS master's program, not a student's UGPA, was a predictor of successful admission into dental school . Extending these results, we report that strong DAT science and reading comprehension scores and attending a mid or highly rigorous undergraduate institution are positive predictors for a strong performance in the OHS program.

Table 5 Dental School Admission by Predictors ( $N=129)$ Mean \pm SD or \%

\begin{tabular}{|c|c|c|c|}
\hline & \multicolumn{2}{|c|}{ Matriculated into dental school } & \multirow[b]{2}{*}{$P$ value } \\
\hline & Yes & No & \\
\hline $\mathrm{N}$ & 121 & 8 & \\
\hline \multicolumn{4}{|l|}{ Undergraduate School Rigor } \\
\hline Low & $83 \%$ & $17 \%$ & \multirow[t]{3}{*}{.034} \\
\hline Mid & $94 \%$ & $6 \%$ & \\
\hline High & $98 \%$ & $2 \%$ & \\
\hline OHS GPA & $3.53 \pm 0.25$ & $3.06 \pm 0.17$ & $<0.001$ \\
\hline Undergraduate GPA & $3.09 \pm 0.26$ & $3.21 \pm 0.28$ & .23 \\
\hline \# Undergraduate BCP credits & $67.7 \pm 19.9$ & $66.3 \pm 23.3$ & .73 \\
\hline \# Undergraduate BCPM credits & $80.0 \pm 21.3$ & $76.8 \pm 28.7$ & .63 \\
\hline \multicolumn{4}{|c|}{ Took undergraduate Anatomy \& Physiology course } \\
\hline Yes & 93 & 7 & \multirow[t]{2}{*}{.73} \\
\hline No & 94 & 6 & \\
\hline \multicolumn{4}{|c|}{ Took undergraduate Biochemistry course } \\
\hline Yes & 94 & 6 & \multirow[t]{2}{*}{.64} \\
\hline No & 92 & 8 & \\
\hline \multicolumn{4}{|c|}{ Took undergraduate Cell Biology course } \\
\hline Yes & 94 & 6 & \multirow[t]{2}{*}{.99} \\
\hline No & 94 & 6 & \\
\hline \multicolumn{4}{|c|}{ Took undergraduate Physiology course } \\
\hline Yes & 94 & 6 & \multirow[t]{2}{*}{.99} \\
\hline No & 94 & 6 & \\
\hline \multicolumn{4}{|c|}{$\%$ B+ or better grade in OHS Physiology } \\
\hline Yes & 99 & 1 & \multirow[t]{2}{*}{.009} \\
\hline No & 87 & 13 & \\
\hline \multicolumn{4}{|c|}{$\% \mathrm{~B}+$ or better grade in OHS Biochemistry } \\
\hline Yes & 99 & 1 & \multirow[t]{2}{*}{.003} \\
\hline No & 84 & 16 & \\
\hline DAT Academic Average & $19.6 \pm 2.0$ & $18.5 \pm 1.4$ & .11 \\
\hline DAT Reading Comprehension & $21.0 \pm 2.5$ & $19.8 \pm 1.2$ & .02 \\
\hline DAT Total Science & $18.9 \pm 1.7$ & $17.9 \pm 1.5$ & .12 \\
\hline
\end{tabular}


Furthermore, OHS students earning a B+ or better in the dental school Physiology and Biochemistry courses taken while enrolled in OHS as a master's student were more successful in matriculating to dental school. Even with weaker admissions credentials (UGPA), OHS graduates who matriculated to BU's School of Dental Medicine performed equally as well as traditional dental students during their first and second year [12] supporting similar results by Holmes et al. [14].

Many studies have sought to clarify admissions criteria that will predict success in medical, dental and doctoral programs. In graduate education, some schools have begun to move towards removal of the GREs from admission requirements [2]. In particular, doctoral programs in the biomedical sciences have begun to evaluate the need for the GRE in admissions and are moving towards a review based on research and academic performance. The study by Park et al. [9] demonstrates that GRE scores only weakly associate with academic success in such a doctoral program and this is further supported by others at University of North Carolina [15] and Vanderbilt [16]. Studies abroad reported of the usage of non-cognitive parameters in admissions. In the UK, changes to the UK Clinical Aptitude Test to include a situational judgement component have taken place to assess non-cognitive components of admission to reduce bias and assess non-cognitive traits $[17,18]$ whereas in dental school admissions, a study by Laia et al. cautioned against using test scores only [19]. Park et al. reported that school rigor or school competitiveness combined with research exposure were found to be strong predictors of success in a biomedical sciences doctoral program [9]. Similarly, our result suggest that attending a strong undergraduate institution correlates with success in the rigorous OHS master's curriculum while students from less rigorous institutions may struggle. Since the major selected and the number of sciences courses did not correlate with success in OHS, we conclude that school rigor may be more important than UGPA in admissions decisions. With this being said, however the MCATs and DATs are still an important piece of the admissions $[6,7,20]$.

Our results support the finding that credentialenhancing master's programs such as OHS can serve to prepare students for success in dental school. We have shown this at BU's School of Dental Medicine but also have tracked OHS graduates who have enrolled in dental schools across the country such as NYU, Tufts, Columbia and Meharry; students completing their dental education at these schools have had equal success. Other dental schools have reported success of students entering dental school following completion of master's program such as that at College of Dental Medicine-Arizona at Midwestern University [21] and those at Tufts and Barry University Biomedical Sciences Master's programs [22].
Since part of OHS's mission is to increase diversity and serve as a pipeline program, one of our goals is to seek other predictors of success that do not compromise students from underrepresented groups and those from disadvantaged backgrounds from bias. Studies have shown that overreliance on GRE scores may compromise admission of students historically underrepresented in STEM [23]. A systematic review of medical school admissions from 2000 to 2014 looked at the importance of interviews including multiple mini-interviews as well as situational judgement tests in addition to test scores and found in general that aptitude tests are considered barriers for applicants from underrepresented groups [24]. Similar results have been shown among dental school applicants [25]. One study further looked at AADSAS application timing and found that students from underrepresented groups tend to apply later in the application cycles and thus are placed at a disadvantage just due to the delay, suggesting there are many approaches that can be implemented to improve the number of applicants and enrollees from underrepresented groups [26].

Keeping this in mind, it would be beneficial if dental schools could more accurately predict which applicants will be successful in the rigorous curriculum with tools other than the DATs that may be a barrier for applicants from underrepresented groups. Our results reported here support the finding that a combination of strong coursework at a rigorous undergraduate (or graduate) institution might be one such tool for the evaluation of cognitive abilities rather than DAT scores. Additionally, means of support must also be in place once students arrive on campus. Schools like Texas A\&M Health Science Center Baylor College of Dentistry have worked to improve enrollment and retention of students from underrepresented groups through strong mentoring programs [27]. Elks et al. at Morehouse Medical School further supported the need to look beyond test scores and have programs in place to strengthen mentoring and academic support to improve academic performance and success on board exams [28] as well as ChavianoMoran at Rutgers School of Dental Medicine [29]. Similarly, mentoring and professional development are a large part of OHS student success with our near-peer program [12]. Supporting students with academic aids, tutors, review sessions in addition to strong peer-peer mentoring and professional develop all contribute in preparing them for the rigors of dental school both academically and professionally.

Will the DATs and the MCATs still be required for admission to professional school? The answer is likely yes, at least in the near future. However, can programs like OHS and other post-baccalaureate credential enhancing master's programs serve to provide a data-driven approach to admissions by using undergraduate courses taken and 
school rigor as an alternative approach to standardized test scores? We believe our results here support this conclusion. Previous studies have looked at undergraduate prerequisites and changes to some admission's requirements have been made [30, 31]. Such trends may be identifiable at individual institutions and support transitioning to using such tools rather than test scores. Specifically, for the master's program at BU, Physiology seems to fit the criteria although at this point the data is not generalizable more broadly. Physiology may be a predictor due to the conceptual nature of the course similar to the reading comprehension DAT score. Plouffe et al. found similar results with regard to Chemistry test scores in a Canadian dental school suggesting more conceptual courses such as Chemistry and Physiology may be able to serve as predictors [6]. Further, the results presented here suggest that students from less rigorous undergraduate institutions may just need more preparatory work such as a master's program [12]. This is extremely relevant to students from underrepresented groups who may have had to work throughout their undergraduate training. Although many of these pipeline programs force applicants to accrue additional debt, it is necessary. Loan-forgiveness programs and scholarships can help to defray the costs. Furthermore, we feel that elucidating additional admission's predictors to assist with pipeline programs is applicable to other postgraduate professional training programs. Understanding alternative predictors of success, we can work to develop guidelines to reduce some of the intrinsic bias in admissions, as it is imperative that committees continue to look beyond the DATs (or the MCATs) to other factors in order to decrease the tremendous gap between professionals from underrepresented groups and the current population they serve.

\section{Conclusion}

We report here that strong test scores, attending a mid or highly rigorous undergraduate institution and completion of an undergraduate Physiology course are positive predictors of future success in the first year of dental school didactic coursework. Further, having students complete a post-baccalaureate master's program is one way to further prepare students for the rigors of dental school. We hope these findings will further refine and guide admission's decisions and improve recruitment to, and future success of, graduate student's pursuit of professional school and in particular pipeline programs. Understanding alternative predictors of success may help to reduce the intrinsic bias among applicants from underrepresented groups and continue to look beyond the DATs (or the MCATs for pre-medical students) to decrease the tremendous gap between professionals from underrepresented groups and the population they serve.

\section{Abbreviations}

BCP: Biology, Chemistry, Physics; BCPM: Biology, Chemistry, Physics, Math; BU: Boston University; DAT: Dental Admissions Test; GPA: Grade point average; GRE: Graduate record exam; MCAT: Medical College Admissions Test; MS: Masters of Science; OHS: Oral Health Sciences;

UGPA: Undergraduate GPA

\section{Acknowledgements}

We would like to acknowledge Boston University's Henry M. Goldman School of Dental Medicine and Graduate Medical Sciences at the School of Medicine for their support in obtaining the data evaluated here.

\section{Authors' contributions}

TAD: Designed the original study concept, collected and de-identified data, reviewed data tables, interpreted the results and reviewed the final document. MBM: Acquisition and interpretation of data from admissions, registrar and programmatic sites. VAM: Background research and draft of final paper, revision of original paper. EAK: Assisted in the design of the original study, drafting the final document and performing all the statistical analysis. Authors have read and approved the manuscript, and ensure that this is the case.

\section{Funding}

No funding was used for the completion of this study.

\section{Availability of data and materials}

The datasets used and/or analyzed during the current study are available from the corresponding author on reasonable request.

\section{Ethics approval and consent to participate}

This study was determined to be EXEMPT by the Institutional Review Board of Boston University Medical Campus, Protocol \# H-33295.

\section{Consent for publication}

Not applicable.

\section{Competing interests}

All authors declare that they have no competing interests.

\section{Author details}

'Department of Medical Sciences \& Education, Boston University School of Medicine, Boston, MA, USA. ${ }^{2}$ Graduate Medical Sciences, Boston University School of Medicine, 72 East Concord Street, L317, Boston, MA 02118, USA. ${ }^{3}$ Department of Health Policy and Health Services Research, Henry M. Goldman Boston University School of Dental Medicine, Boston, MA, USA.

Received: 20 July 2019 Accepted: 8 January 2020

Published online: 15 January 2020

\section{References}

1. Price MD, Park SE. Can noncognitive components of admissions data predict dental student performance and postdoctoral program placement? J Dent Educ. 2018;82(10):1051-8.

2. Miller C, Stassun K. A test that fails. Nature. 2014;510(7504):303-4.

3. Sandow PL, Jones AC, Peek CW, Courts FJ, Watson RE. Correlation of admission criteria with dental school performance and attrition. J Dent Educ. 2002:66(3):385-92.

4. Park SE, Susarla SM, Massey W. Do admissions data and NBDE part I scores predict clinical performance among dental students? J Dent Educ. 2006; 70(5):518-24.

5. Lee KC, Lee WY, Zubiaurre LA, Grbic JT, Eisig SB. Relationship between dental students' pre-admission record and performance on the comprehensive basic science examination. J Dent Educ. 2018;82(4):424-8.

6. Plouffe RA, Hammond R, Goldberg HA, Chahine S. What matters from admissions? Identifying success and risk among Canadian dental students. J Dent Educ. 2018:82(5):515-23.

7. Rowland KC, Rieken S. Rethinking dental school admission criteria: correlation between pre-admission variables and first-year performance for six classes at one dental school. J Dent Educ. 2018;82(4):411-6. 
8. Carroll AM, Schuster GM. Correlation between students' dental admission test scores and performance on a dental school's competency exam. J Dent Educ. 2015;79(11):1325-9.

9. Park H-Y, Berkowitz O, Symes K, Dasgupta S. The art and science of selecting graduate students in the biomedical sciences: performance in doctoral study of the foundational sciences. PLoS One. 2018;13(4):e0193901.

10. Humphrey-Murto S, Leddy JJ, Wood TJ, Puddester D, Moineau G. Does emotional intelligence at medical school admission predict future academic performance? Acad Med. 2014;89(4):638-43.

11. Libbrecht N, Lievens F, Carette B, Côté S. Emotional intelligence predicts success in medical school. Emotion. 2014;14(1):64-73.

12. Davies TA. Improving diversity and the dental pipeline through Boston University's Oral Health Sciences postbaccalaureate masters program. J Dent Educ. 2019;83(3):287-95.

13. Profiles of American Colleges 2015 (Barron's Profiles of American Colleges): Barron's college division staff: 9781438004297 : Amazon.com: Books [Internet]. Available from: https://www.amazon.com/Profiles-AmericanColleges-2015-Barrons/dp/143800429X. [cited 2018 Dec 26]

14. Holmes DC, Doering JV, Spector M. Associations among predental credentials and measures of dental school achievement. J Dent Educ. 2008; 72(2):142-52.

15. Hall JD, O'Connell AB, Cook JG. Predictors of student productivity in biomedical graduate school applications. PLoS One. 2017;12(1):e0169121.

16. Moneta-Koehler L, Brown AM, Petrie KA, Evans BJ, Chalkley R. The limitations of the GRE in predicting success in biomedical graduate school. PLoS One. 2017;12(1):e0166742 pmid:28076356.

17. Finn GM, Mwandigha L, Paton LW, Tiffin PA. The ability of 'non-cognitive' traits to predict undergraduate performance in medical schools: a national linkage study. BMC Med Educ. 2018;18(1):93.

18. Cousans F, Patterson F, Edwards H, Walker K, McLachlan JC, Good D. Evaluating the complementary roles of an SJT and academic assessment for entry into clinical practice. Adv Health Sci Educ Theory Pract. 2017;22(2): 401-13.

19. Lala R, Wood D, Baker S. Validity of the UKCAT in applicant selection and predicting exam performance in UK dental students. J Dent Educ. 2013; 77(9):1159-70

20. Dunleavy DM, Kroopnick MH, Dowd KW, Searcy CA, Zhao X. The predictive validity of the MCAT exam in relation to academic performance through medical school: a national cohort study of 2001-2004 matriculants. Acad Med. 2013:88(5):666-71.

21. Johnson GM, Buros AF, Lukas RW. Comparison of postbaccalaureate and baccalaureate graduates' performance in first and second years of dental school. J Dent Educ. 2018;82(9):929-35.

22. Johnson GM, Polk HH, Huvel SDVD, Ferguson GP, Soby SD. A comparison of seven predental postbaccalaureate programs in gaining dental school acceptance for their students. J Dent Educ. 2017:81(5):526-33.

23. Petersen SL, Erenrich ES, Levine DL, Vigoreaux J, Gile K. Multi-institutional study of GRE scores as predictors of STEM PhD degree completion: GRE gets a low mark. PLoS One. 2018;13(10):e0206570.

24. Kelly ME, Patterson F, O'Flynn S, Mulligan J, Murphy AW. A systematic review of stakeholder views of selection methods for medical schools admission. BMC Med Educ. 2018;18(1):162

25. Ranney RR, Wilson MB, Bennett RB. Evaluation of applicants to predoctoral dental education programs: review of the literature. J Dent Educ. 2005; 69(10):1095-106.

26. Aalboe JA, Harper C, Beeman CS, Paaso BA. Dental school application timing: Implications for full admission consideration and improving diversity of dental students. J Dent Educ. 2014;78(4):575-9.

27. Lacy ES, Miller BH, Hornback SA, AL MC, Reuben JS. Retention of underrepresented minority students in dental school: one dental schools story. J Am Coll Dent. 2011;78(4):40.

28. Elks ML, Herbert-Carter J, Smith M, Klement B, Knight BB, Anachebe NF. Shifting the curve: fostering academic success in a diverse student body. Acad Med. 2018;93(1):66-70.

29. Chaviano-Moran R, Chuck E, Perez H. Unintended demographic bias in GPA/DAT-based pre-admission screening: an argument for holistic admissions in dental schools. J Dent Educ. 2019;83(11):1280

30. Humphrey SP, Mathews RE, Kaplan AL, Beeman CS. Undergraduate basic science preparation for dental school. J Dent Educ. 2002;66(11):1252-9.
31. Geissberger MJ, Jain P, Kluemper GT, Paquette DW, Roeder LB, Scarfe WC, Potter BJ. Realigning biomedical science instruction in predoctoral curricula: a proposal for change. J Dent Educ. 2008;72(2):135-41.

\section{Publisher's Note}

Springer Nature remains neutral with regard to jurisdictional claims in published maps and institutional affiliations.
Ready to submit your research? Choose BMC and benefit from:

- fast, convenient online submission

- thorough peer review by experienced researchers in your field

- rapid publication on acceptance

- support for research data, including large and complex data types

- gold Open Access which fosters wider collaboration and increased citations

- maximum visibility for your research: over $100 \mathrm{M}$ website views per year

At BMC, research is always in progress.

Learn more biomedcentral.com/submissions 